\title{
DETERMINANTS OF BANK PERFORMANCE IN INDONESIA
}

\author{
Bahtiar Usman \& Henny Setyo Lestari* \\ Faculty of Economics and Business, Universitas Trisakti, Indonesia
}

\begin{abstract}
This study aims to examine the determinants of commercial banks' performances in Indonesia in the period 2008-2017 by their return on assets. Capital adequacy, asset quality, management efficiency and liquidity, and gross domestic product functioned as the predictors. The sample of this study was 25 conventional banks meeting the criteria of the purposive sampling method. The panel data with Eviews shows that asset quality has a negative effect, and management efficiency has a positive impact on bank performance. Capital adequacy, liquidity, and gross domestic product growth rate do not affect the bank's performance. Managers need to tighten lending, carry out credit restructuring, and manage the balance between assets and liabilities and, supervise credit.
\end{abstract}

Keywords: Asset Quality, Bank Performance, Capital Adequacy, Gross Domestic Product, Liquidity, Management Efficiency.

*Corresponding author: henny_setyo_lestari@trisakti.ac.id

DOI: $10.24252 /$ minds.v6i2.11282 


\section{INTRODUCTION}

The banking sector plays a critical role as a driver of economic growth and creates equity in Indonesia. Based on the amount of Gross Domestic Product (GDP) obtained from the Central Statistics Agency (BPS), shows that the Indonesian economy in the second quarter of 2018 experienced growth from the previous year, both in terms of production and expenditure. Minister of Finance Sri Mulyani Indrawati on May 15, 2018, stated that the banking industry had a significant role in supporting economic growth and creating equity.

Banks have an essential role in a country's economic system, which is described by operational continuity if managed effectively and efficiently. The smooth flow of funds from the owners of capital to the borrowers, increased profitability, and excellent services illustrate the bank's financial system running well (Sufian \& Habibullah, 2009). Banks allocate economic resources in a country by continuing to channel funds from depositors to investors (Ongore and Kusa, 2013). According to Jha and Hui (2012), evaluating bank performance is related to how well banks can use assets, equity, liabilities, income, and manage costs.

Ali, Akhtar, and Ahmed (2011) found that the health of a bank is subject to internal and external factors (macro). Thus, this study provided a new means of analyzing banks' performance by its internal and external factors simultaneously, instead of focusing on just one aspect. Bank internal factors can be measured by analyzing bank financial ratios based on the CAMEL framework. CAMEL framework is used in various studies to examine the health of a bank. CAMEL framework includes capital adequacy, asset quality, management efficiency, and liquidity (Haidary dan Abbey, 2018). External (macro) factors require statistical information and secondary sources in the economic environment (Haidary and Abbey, 2018). Gross domestic product (GDP), inflation, and interest rate are macro factors that affect profitability (Alper and Anbar, 2011). Based on the background above, this study aims to analyze the determinants that influence bank performance.

\section{THEORETICAL REVIEW}

\section{Bank Performance}

Banking performance is a picture of the economic success achieved by banks in a certain period of bank activities to generate profits effectively and efficiently (Ayanda, Christoper \& Mudhasiru, 2013). It is crucial to assess the financial performance of a bank to see how the bank performs, whether it is already good or not. A valuation can also find out how much profitability or bank profit by comparing the results of profits in specific periods with earnings in the years before and after or comparing the performance of one bank with other banks (Katrodia, 2012). Zainuddin, Wancik, Rahman, Hartati, and Rahman (2017) say that profitability is an indicator to measure bank performance. Menicucci and Paolucci (2016) state that profitability is the ability to run performance within the bank to earn profits from year to year. One of the measurements of bank profitability is using the return on assets (ROA), taking into account the ability of banks to earn overall assets (Lipunga, 2014). ROA is a 
bank's management ability to generate income by utilizing the assets. ROA shows the effective and efficient use of company assets to create profits (Kingu, Macha, and Gwahula, 2018). Another opinion was expressed by Haidary and Abbey (2018) who said that ROA evaluates returns based on the entire base of bank assets, including capital invested by the owner and customer deposits.

\section{Capital Adequacy}

Capital adequacy is a crucial measure of the sustainability of a bank. Capital adequacy ratio (CAR) is a ratio that is very commonly used by banks. CARprovide guarantees and convenience to bank depositors and serve as security for customer deposits and help smooth operations. The ratio works by comparing total capital with total assets. Total capital only includes ordinary shares, money invested by owners, and bank-related reserves. CAR shows the proportional balance of assets in the bank between owners and depositors (Haidary and Abbey, 2018). Capital adequacy is an indicator to determine the financial health and health of banks. The capital adequacy of the bank can determine whether the bank has sufficient resources to bear unexpected losses in the future (Asphalt and Dhawan, 2014).

Several studies discussed the relationship between CAR and profitabilities. Haidary and Abbey (2018) and Eljelly (2013) found that there is a positive influence between capital adequacy and ROA. This influence shows that the higher the capital of a bank will affect the level of public trust in their savings. The higher CAR ratio indicates the better the bank's performance in managing its money and carrying out its operational activities efficiently so that the bank's profitability increases which in turn increases bank performance. A different study conducted by Erina and Lace (2013) found that there was a significant adverse effect between capital adequacy and ROA, which reflected that banks were too cautious in using their capital and missed opportunities to expand their businesses that could increase profits for banks. Banks should be able to maximize their holdings to grow their company to increase revenue for banks.

\section{Asset Quality}

Another quality of the bank is its asset strength. According to Ongore and Kusa (2013), bank assets are specific variables that affect bank profitability. Bank assets include loans, fixed assets, and other investments. Asset growth is related to the age of the bank. Bank loans are the main assets of commercial banks in generating income. The quality of the loan portfolio has a direct bearing on bank profitability. The highest risk faced by banks is losses from non-performing loans. As such, the nonperforming loan (NPL) ratio is the best measure for measuring asset quality. Asset quality works by comparing nonperforming loans to its total loans. Tsz-Yi, Li, and Yung-Ho (2011) explained that loans are one of the main outputs provided by banks, but lending can also produce risks, causing banks to produce poor performance. A bank with more loans does not always have high efficiency, mainly if it is associated with the increase of non- 
performing loans. Ongore and Kusa (2013) and Adeusi et al. (2014) found that there was a significant adverse effect between asset quality and ROA. This influence shows that the rate of return on earning assets has decreased due to the excessive amount of loans at risk.

\section{Management Efficiency}

Management efficiency is the ability of bank management in available resources. Management efficiency measurement is by comparing interest income with interest expense (Adeusi et al., 2014). According to Ongore and Kusa (2013), management efficiency is one of the main internal factors that determine bank profitability. Asset growth, credit growth rates, and income levels reflect management efficiency. Management efficiency is the ability of management to use resources efficiently, maximize revenue, reduce operating costs. The results of research conducted by Haidary and Abbey (2018) and Ongore and Kusa (2013) show that there is a significant positive effect between management efficiency and ROA. This influence indicates that if bank management has to manage its resources efficiently and reduce waste so that costs incurred by banks are lower. The lower costs incurred will undoubtedly have an impact, namely increased income for banks. Different research found by Adeusi et al., (2014) shows that there is a significant adverse effect between management efficiency on ROA which indicates that higher costs reflect lower profits, the impact may not be immediate. The higher amount of costs can be subject to the higher volume of banking activities which causes higher income.

\section{Liquidity}

Liquidity is the ability of a business to meet obligations when due. Banks must maintain sufficient short-term liquid assets to meet short-term requirements, especially on customer deposits. Bank liquidity is a trade-off for profitability. Maintaining the level of liquidity means the availability of cash, cash not related to investment, less risk will result in lower returns. Liquidity can be measured by a loan to deposits ratio (LDR) by comparing the total loans with the overall customer deposits (Haidary and Abbey, 2018). Ongore and Kusa (2013) stated that liquidity is the ability of banks to fulfill their obligations, especially from depositors. Haidary and Abbey (2018) found that there was no influence between liquidity and ROA which indicated the number of bad loans illustrating that loans provided had less impact on bank income. Different results found by Nisar, Peng, Wang, and Ashraf (2018) and Al-Tamimi (2010), states that there is a positive and significant effect between liquidity and ROA which indicates the higher the amount of the loan, the higher the bank gets a profit in the form of credit interest. When banks have a lot of capital customers, they tend to make loans, thereby increasing bank profits.

\section{GDP Growth Rate}

The external issue also matters. Messai, Gallalim, and Jouini (2015) revealed that economic growth was measured using a gross domestic product 
(GDP) growth rate of GDP growth rate. The low level of GDP growth and the decline in the level of GDP have an impact on the decrease in the quality of bank credit. Boateng (2018) states that gross domestic product (GDP) refers to the total market value of all goods and services produced in a country per year. GDP is the primary indicator of economic growth that shows the level of productivity of a country (Adeusi et al., 2014). Ali et al. (2011) and Boadi, Li, and Lartey (2016) explain that GDP growth rate has a positive effect on ROA which indicates that GDP growth rate leads to higher public consumption so that demand for bank credit increases. When the need for credit increases, the bank will benefit from credit interest. Different results were found by Tan and Floros (2012) who found that the GDP growth rate decreases the level of ROA. With the increasing demand for credit, banks are increasingly aggressive in offering lower interest rates, thereby creating competition between one bank with another bank. This interbank competition will reduce bank income because customers will choose banks with lower mortgage interest. The decline in revenue reflects the bank's declining performance. Haidary and Abbey (2018) also found that the GDP growth rate did not affect $\mathrm{ROA}$.

All of these different correlations among variables create a new window of research. This study thus tries to investigate and clarify the debate in Indonesia's experience. Therefore, the following conceptual relationships are:

\section{Independent Variable}

Dependent Variable

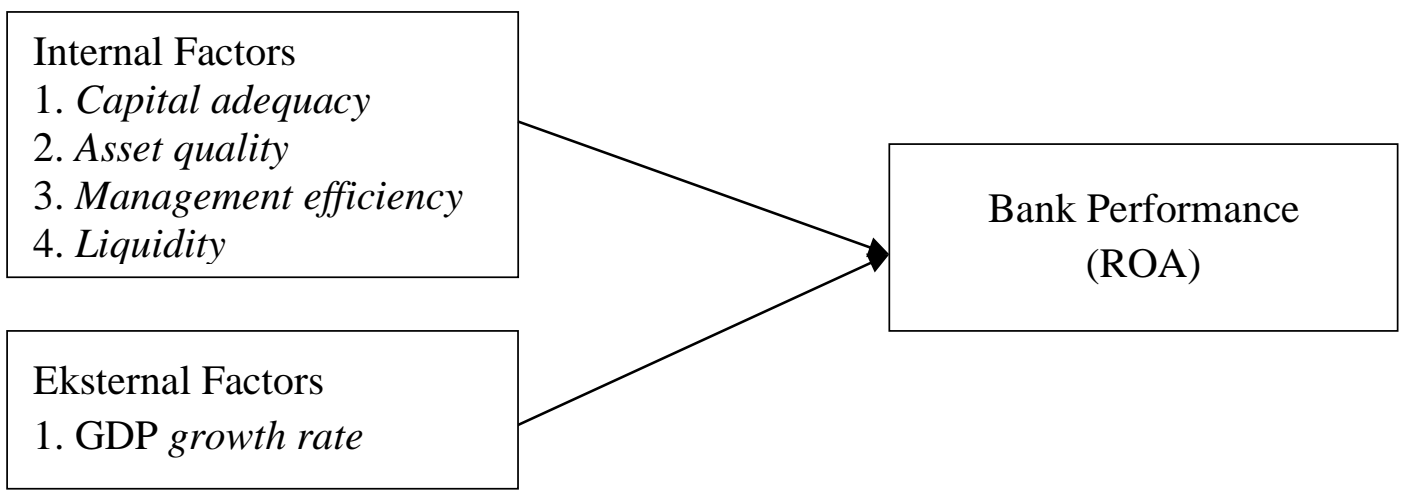

Figure 1. Conceptual Framework of Research

\section{METHODOLOGY}

The research design conducted in this study is a quantitative study using hypothesis testing. Hypothesis testing aims empirically to test hypotheses by looking at the effect of capital adequacy, asset quality, management efficiency, liquidity, and GDP growth rate on the dependent variable, namely bank performance measured using ROA. The data used in this study is panel data. Sampling with a purposive sampling method obtained as many as 25 conventional banks listed on the Indonesia Stock Exchange during the period 2008-2017. The data used is panel data tested with Eviews version 9 software. 


$$
\mathrm{ROA}=\alpha+\beta_{1} \mathrm{CAR}+\beta_{2} \mathrm{NPL}+\beta_{3} \mathrm{EFF}+\beta_{4} \mathrm{LDR}+\beta_{5} \mathrm{GDPGR}+\epsilon
$$

Where :

$\begin{array}{ll}\text { ROA } & : \text { Return on asset } \\ \text { a } & : \text { Konstanta } \\ \beta_{(1-5)} & : \text { coefficient of explanatory variables } \\ \text { CAR } & : \text { Capital adequacy } \\ \text { NPL } & : \text { Asset quality } \\ \text { EFF } & : \text { Management efficiency } \\ \text { LDR } & : \text { Liquidity } \\ \text { GDPGR } & : \text { GDP growth rate } \\ \in & : \text { regression residual }\end{array}$

Table 1

Research Variables Measurements

\begin{tabular}{|c|c|c|}
\hline Varaiables & Measurements & Simbols \\
\hline \multicolumn{3}{|l|}{ Independent } \\
\hline \multicolumn{3}{|l|}{ Variables } \\
\hline Capital Adequacy & Total Capital/Total Assets & CAR \\
\hline \multicolumn{3}{|l|}{ Ratio } \\
\hline Asset Quality & $\begin{array}{l}\text { Non-performing Loans/Total } \\
\text { Loans }\end{array}$ & NPL \\
\hline Management & Interest Income/Interest Expense & $\mathrm{EFF}$ \\
\hline \multicolumn{3}{|l|}{ Efficiency } \\
\hline Liquidity & $\begin{array}{l}\text { Total Loans/Total Customer } \\
\text { Deposits }\end{array}$ & LDR \\
\hline GDP Growth Rate & $\begin{array}{l}\text { The year-on-year GDP growth } \\
\text { rate }\end{array}$ & GDPGR \\
\hline \multicolumn{3}{|l|}{ Dependent variables } \\
\hline Bank Performance & Profit After Tax/Total Assets & $\mathrm{ROA}$ \\
\hline
\end{tabular}

\section{RESULT}

Descriptive statistical analysis shows the minimum and maximum values of each variable. The minimum amount is the lowest value for each variable, while the maximum score is the highest value for each variable in the study. The mean is the average amount of each variable studied. Standard deviation is the distribution of data used in research that reflects the data is heterogeneous or homogeneous. The following are descriptive statistics of the variables used: 
Table 2

Descriptive Statistics

\begin{tabular}{|c|c|c|c|c|c|}
\hline Variable & Mean & Max & Min & Std. Dev & N \\
\hline ROA & 0.012820 & 0.098167 & -0.117665 & 0.016170 & 250 \\
\hline CAR & 0.123082 & 0.250000 & 0.056189 & 0.035152 & 250 \\
\hline NPL & 0.026351 & 0.158200 & 0.002100 & 0.018246 & 250 \\
\hline EEF & 2.151108 & 6.939314 & 1.163482 & 0.711244 & 250 \\
\hline LDR & 0.818309 & 1.133004 & 0.397816 & 0.130375 & 250 \\
\hline GDPGR & 0.055380 & 0.064900 & 0.046300 & 0.006484 & 250 \\
\hline
\end{tabular}

Sources: Output Data Eviews 9

Table 3

Best Model Selection

\begin{tabular}{ll}
\hline Model Test & Best Model \\
\hline Uji Chow & Fixed Effect \\
Uji Hausman & Random Effect \\
Uji LM & Common Effect \\
\hline
\end{tabular}

This study found that the best model in this research was the random effect model. The estimation in the random effect model works from General Least Square (GLS) until the examination of classic assumptions can be ignored. The result on the analysis of the effect among the funding size, leverage, Loan Loss Reserve, Net Interest Margin, Loan Asset ratio and liquidity towards Capital Adequacy Ratio on the random effect model (LM test) is in Table 3.

Table 4

Result t Test

\begin{tabular}{|c|c|c|c|}
\hline Variabel & Coef & Prob & Conclusion \\
\hline CAR & -0.030498 & 0.2383 & Insignificant \\
\hline NPL & -0.452520 & 0.0000 & Significant \\
\hline EEF & 0.005672 & 0.0001 & Significant \\
\hline LDR & 0.003412 & 0.6501 & Insignificant \\
\hline GDPGR & -0.170856 & 0.1688 & Insignificant \\
\hline
\end{tabular}

Sources: Output Data Eviews 9

\section{DISCUSSION}

\section{Capital Adequacy}

The results of this study indicate that capital adequacy does not affect bank performance (ROA). This study is not in line with research conducted by Haidary and Abbey (2018) who found that capital adequacy has a positive and significant effect on ROA. Kingu et al. (2018) found that capital adequacy has a positive impact on ROA which indicates that banks can utilize their funds to fund asset growth and increase profits, thereby reducing bank dependence on external funding. External funding will add burden to the bank because the bank must 
pay the principal installments as well as additional interest so that it charges costs and reduces income for the bank. Research that supports the results of this study is a study conducted by Adeusi et al. (2014) found that there was no influence between capital adequacy on ROA. The results of the study are in line with research conducted by Weersainghe and Perera (2013), finding that capital adequacy has no effect on ROA which indicates that the size of the capital owned by banks has less impact on bank income. A capital adequacy ratio is needed only to measure the health of a bank under Bank Indonesia regulations, which is a minimum of $8 \%$.

\section{Asset Quality}

The results of this study stated that asset quality has a significant adverse effect on bank performance (ROA). This study is in line with research conducted by Ongore and Kusa (2013) found that asset quality has a significant negative effect on ROA. Anbar and Alper (2011) found that asset quality has a significant negative impact on ROA, which illustrates that assets owned by banks are unable to cover losses due to excessive credit volume, increasing costs, both the cost of reserves for productive assets and other expenses that cause bank revenues to decline. The decline in bank income can affect bank performance and be an indicator that banks have poor asset quality because they pay less attention to the principle of prudence in granting credit. This result is in line with Adeusi et al. (2014), who found that asset quality negatively affects ROA. This influence shows that the rate of return on earning assets has decreased due to too high the number of problem loans, lowering interest income so that it produces unexpected returns.

\section{Management Efficiency}

This study found that management efficiency has a significant positive effect on bank performance (ROA). This finding contradicts Adeusi et al. (2014) showing that there is a significant adverse effect between management efficiency on ROA. This study is in line with research conducted by Haidary and Abbey (2018) found that management efficiency has a significant positive effect on ROA that reflects excellent bank performance. This influence shows that bank management can manage its resources efficiently and reduce waste so that costs incurred by banks are lower. Another study conducted by Ongore and Kusa (2013) found similar results that management efficiency has a positive effect on ROA which indicates that when interest rates rise, both interest income and interest costs will increase because some assets and liabilities will be valued at a higher level. Management efficiency shows more effective banks in the placement of productive assets in the form of credit so that it will increase profits for banks. Thus, the magnitude of management efficiency affects bank profit and loss which ultimately affects bank performance. 


\section{Liquidity}

This study found that liquidity does not affect bank performance (ROA). This study is in line with research conducted by Haidary and Abbey (2018) who found that liquidity did not affect ROA. A different result found by Al-Tamimi (2010) found that there is a positive influence between liquidity and ROA which indicates the rapid credit distribution of customer deposits so that it will increase bank profits. The more credit given, the bank will get income from loan interest. Research that supports the results of this study is a study conducted by Adeusi et al. (2014) showing that liquidity does not affect ROA. This study is also in line with research conducted by Almumani (2013) stating that liquidity would not affect ROA. High and low liquidity owned by banks does not affect the bank's performance. The existence of bad loans reflects the amount of credit given less impact on banking performance.

\section{GDP Growth Rate}

GDP represents the external factor that could affect bank performance. This study found that the GDP growth rate does not influence the bank performance (ROA). These results are in line with research conducted by Haidary and Abbey (2018) which shows that the GDP growth rate does not influence the performance of banks measured to soften ROA. Boadi et al. found a different result (2016) found a significant positive effect on GDP growth rate with ROA which indicates that GDP growth rate leads to higher public consumption so that demand for bank credit increases. When the need for credit increases, the bank will benefit from credit interest. The results of this study are in line with research conducted by Anbar and Alper (2011) who found no effect between GDP growth rate on bank performance because the GDP growth rate is the level of state revenue that does not significantly affect the profitability of banks because the level of GDP growth rate is an external factor that if the company has good financial infrastructure internally, it will not be affected by the GDP growth rate.

\section{FURTHER STUDY}

This study aims to determine the significant effect between capital adequacy, asset quality, management efficiency, liquidity, and GDP growth rate on bank performance (ROA). This study uses 25 banks listed on the Indonesia Stock Exchange during the period 2008-2017. Further studies could explore the more profound exchange of internal and external factors affecting banks' performance. A better look at the critical elements of competitive advantage in the banking system would strategically provide an edge in decision making.

\section{REFERENCES}

Adeusi, S. O., Kolapo F. T., dan Aluko, A. O., (2014). Determinants of Commercial Banks Profitability. International Journal of Economics, Commerce and Management, 2 (12), 1-18. http://ijecm.co.uk/ 
Ali, K., Akhtar, M. F., dan Ahmed, H. Z. M. F. (2011). Bank-Specific and Macroeconomic Indicators of Profitability -Empirical Evidence from the Commercial Banks of Pakistan. International Journal of Business and Social Science, 2 (6), 235-242. https://www.researchgate.net/

Alkhatib, A., dan Harasheh, M. (2012). Financial Performance of Palestinian Commercial Banks. International Journal of Business and Social Science, 3 (3), 175-184. http://ijbssnet.com/

Almumani, M. A. (2013). Impact of Managerial Factors on Commercial Bank Profitability: Empirical Evidence from Jordan. International Journal of Academic Research in Accounting, Finance, and Management Science, 3 (3), 298310. http://hrmars.com/

Al-Tamimi, H. A. H. (2010). Factors Influencing Performance of The UAE Islamic and Conventional National Banks. Global Journal of Business Research, 1.4 (2), 1-9. http://www.theibfr2.com/

Anbar, A., dan Alper, D. (2011). Bank Specific and Macroeconomic Determinants of Commercial Bank Profitability: Empirical Evidence from Turkey. Business and Economics Research, 2 (2), 1309-2448.https://www.berjournal.com/

Aspal, P. K., dan Dhawan, S. (2014). Financial Performance Assessment of Banking Sector in India: A Case Study of Old Private Sector Banks. The business and Management Review, 5 (3), 196-211. http://www.abrmr.com

Ayanda, A. M., Christoper, E. I., dan Mudhasiru, M. A. (2013). Determinants of Bank's Profitability in Developing Economy: Evidence from Nigeria Banking Industry. Interdisciplinary Journal of Contemporary Research In business, 4, 155181. https://journal-archieves27.webs.com/155-181.pdf

Boadi, E. K., Li, Y., dan Lartey, V. C. (2016). Role of Bank Specific, Macroeconomic and Risk Determinants of Banks Profitability: Empirical Evidence from Ghana 's Rural Banking Industry. International Journal of Economics and Financial Issues, 6(2), 813-823. https://ideas.repec.org/

Boateng, K. (2018). Determinants of Bank Profitability : A Comparative Study of Indian and Ghanaian Banks. Journal of Emerging Technologies and Innovative Research, 5 (5), 643-654. https://www.researchgate.net/

Eljelly, A. M. A. (2013). Internal and External of Determinants of Probability of Islamic Banks in Sudan : Evidence from Panel Data. Afro-Asian J. Finance and Accounting, 3 (3), 222-240. https:// www.inderscienceonline.com/

Erina, J., dan Lace, N. (2013). Commercial Banks Profitability Indicators: Empirical Evidence from Latvia. IBIMA Business Review, 13, 1-9. https://ibimapublishing.com/articles/IBIMABR/2013/873515/

Haidary, Q., dan Abbey B. (2018). Financial Performance of Commercial Banks in Afghanistan. International Journal of Economics and Financial Issues, 8 (1), pp.242-249. https:// www.econjournals.com

Jha, S., dan Hui, X. (2012). Comparison of Financial Performance of Commercial Banks: A Case Study of Nepal. African Journal of Business Management, 6 (25), 7601-7611. http://www.academicjournals.org/

Katrodia, A. (2012). Corporate Governance Practices in The Banking Sector. ABHINAV Journal of Research in Commerce and Management, 1, 37-44. http://www.abhinavjournal.com/ 
Kingu, P. S., Macha, S., dan Gwahula, R. (2018). Impact of Non-Performing Loans on Bank's Profitability: Empirical Evidence from Commercial Banks in Tanzania. International Journal of Scientific Research and Management, 6 (1), 7178. https://ijsrm.in/index.php/ijsrm/article/download/1257/1115/

Lelissa, T. B. (2014). The Determinants of Ethiopian Commercial Banks Performance. European Journal of Business and Management, 6 (14), 52-63. www.iiste.org

Lipunga, A. M. (2014). Determinants of Profitability of Listed Commercial Banks in Developing Countries: Evidence from Malawi. Research Journal of Finance and Accounting, 5 (6), 41-49. https:// www.academia.edu/7199973/

Menicucci, E., dan Paolucci, G. (2016). The Determinants of Bank Profitability: Empirical Evidence from European Banking Sector. Journal of Financial Reporting and Accounting, 14 (1), 86-115. https:// www.emeraldinsight.com/

Messai, A. S., Gallalim M. I., dan Jouini, F. (2015). Determinants of Bank Profitability in Western European Countries Evidence from System GMM Estimates. International Business Research, 8 (7), 30-41. http://www.ccsenet.org/

Mills, E. F. E. A., dan Amowine, N. (2013). The Rural Bank Profitability Nexus : Evidence from Ghana. International Journal of Applicant or Innovation in Engineering and Management, 12 (4), 506-513. https://www.researchgate.net/publication/272171355

Nagaraju, Y., dan Boateng, K. (2018). Profitability Determinants of Savings and Loans Companies in Ghana: Evidence on Bank Specific and Macroeconomic Determinants. International Journal of Management Studies, 5 (2), 51-60. http://www.researchersworld.com/ijms/

Nisar, S., Peng, K., Wang, S., dan Ashraf, B. N. (2018). The Impact of Revenue Diversification on Bank Profitability and Stability: Empirical Evidence from South Asian Countries. International Journal of Financial Studies 6 (40), 1-25. https://www.mdpi.com/

Olweny, T., dan Shipho, T.M. (2011). Effect of Banking Sectoral Factors on The Profitability Of Commercial Banks in Kenya. Economics and Finance Review, 1 (5), 1-30. http://wwww.businessjournalz.org/efr

Ongore, V. O., dan Kusa, G. B. (2013). Determinants of Financial Performance of Commercial Banks in Kenya. International Journal of Economics and Financial Issues, 3 (1), 237-252. www.econjournals.com

Republika Indonesia.1998. Undang-Undang No.10 Tahun 1998 tentang Perbankan perubahan atas Undang-Undang No. 14 Tahun 1992 tentang Perbankan. Sekretariat Negara. Jakarta.

Rim, E. K., dan Salem, C. G. (2018). Ranking and Rating Lebanese Commercial Banks : A CAMELS Framework. International Academic Journal of Accounting and Financial Management, 5 ( 4), 49-65. http://iaiest.com/

Saif-Alyousfi, A. Y. H., Saha, A., dan Md-Rus, R. (2017). The profitability of Saudi Commercial Banks: A Comparative Evaluation between Domestic and Foreign Banks Using CAMEL Parameters. International Journal of Economics and Financial Issues, 7 (2), 477-484. http:// dergipark.gov.tr/ 
Sufian, F., dan Habibullah, M. S. (2009). Bank Specific and Macroeconomic Determinants of Bank Profitability: Empirical Evidence from The ChinaBanking Sector. Frontiers of Economics in China, 4 (2), 274-291. https://link.springer.com/

Tan, Y., dan Floros, C. (2012). Banks Profitability and GDP Growth in China: a note. Journal of Chinese Economics and Business Studies, 10 (3), 267-273. https://researchportal.port.ac.uk/

Tsz-Yi, K., Li Y., dan Yung-Ho, C. (2011). Analyzing for Profit Efficiency of Banks with Undesirable Output. African Journal of Business Management, 5 (20), 8141-8149. http://www.academicjournals.org/AJBM

Weersainghe, V. E. I. W., dan Perera, T. R. (2013). Determinants of Profitability of Commercial Banks in Srilanka. International Journal of Arts and Commerce, 2 (10), 141- 170. https://www.ijac.org.uk

Zainuddin, P., Wancik, Z., Rahman, S. A., Hartati, S., dan Rahman, F. A. (2017). The determinant of Financial Performance on Indonesian Banks Through Return on Assets. International Journal of Applied Business and Economic Research, 15 (20), 243-251. https://www.researchgate.net/

Zheng, C., Rahman, M. M., Begum, M., dan Ashraf, B. N. (2017). Capital Regulation, the Cost of Financial Intermediation and Bank Profitability: Evidence from Bangladesh. Journal of Risk and Financial Management, 10 (9), 1-24. https://www.mdpi.com/

www.bps.co.id

www.idx.co.id

https://m.liputan6.com/bisnis/read/3526017/kata-sri-mulyani-soal-peranan

perbankan-dalam-mendorong-ekonomi-ri (diakses pada 14 Oktober 2018) 